\title{
Gallbladder Leiomyosarcoma
}

National Cancer Institute

\section{Source}

National Cancer Institute. Gallbladder Leiomyosarcoma. NCI Thesaurus. Code C5841.

An aggressive malignant smooth muscle neoplasm, arising from the gallbladder. It is characterized by a proliferation of neoplastic spindle cells. 